\title{
PENYULUHAN DETEKSI DINI KANKER SERVIKS DAN KANKER PAYUDARA PADA KOMUNITAS PEDAGANG CANANG DI PASAR KRENENG DENPASAR UTARA
}

\author{
M Dharmesti Wijaya ${ }^{1}$, AAG Indraningrat ${ }^{2}$, DAP Sri Masyeni ${ }^{3}$, Agus Santosa $^{4}$
}

\begin{abstract}
ABSTRAK
Kanker payudara dan kanker serviks merupakan jenis kanker dengan prevalensi dan angka kematian tertinggi pada wanita. Namun, deteksi dini ternyata dapat menurunkan angka kematian akibat kanker payudara secara signifikan dan skrining yang efektif serta pengobatan lesi pra-kanker dapat menurunkan angka kejadian kanker serviks. Oleh karena itu, pemberdayaan kelompok-kelompok masyarakat dalam meningkatkan kesadaran akan pentingnya pengetahuan mengenai deteksi dini gejala dan tanda, serta langkah pencegahan kanker payudara dan kanker serviks sangat dibutuhkan. Anggota kelompok masyarakat yang diberdayakan diharapkan dapat menjadi kader yang dapat membantu program pemerintah dalam memberikan edukasi mengenai deteksi dini kanker payudara dan kanker serviks kepada anggota kelompoknya, kelompok masyarakat lain, serta keluarga kader. PKMS ini memberikan pelatihan kepada kelompok penjual canang di Pasar Kreneng Denpasar mengenai penyakit kanker payudara dan kanker serviks beserta metode deteksi dini kanker tersebut.
\end{abstract}

Kata kunci: kanker payudara, kanker serviks, deteksi dini, pemberdayaan masyarakat

\begin{abstract}
Breast and cervical cancers are type of cancers with the highest prevalence among women and contribute to high mortaliy rate in this group. Evidently, early detection could significantly reduce the mortality rate of breast cancer while effective screening and treatment of precancerous lesions could make the cervical cancer largely preventable. Therefore, the empowerment of women social groups within the society plays an important role to raise awareness of the symptoms of breast and cervical cancers. Our community service activity aimed to train and educate cadres that represent a group of canang sellers at the Kreneng Market Denpasar with regard to breast and cervical cancers including symptoms and methods for an early detection. We expect that these selected cadres can actively socialize the breast and cervical cancers early detection methods for their group members, related families, and also people within their neighbourhood.
\end{abstract}

Keywords: breast cancer, cervical cancer, early detection, community empowerment

${ }^{1}$ Fakultas Kedokteran dan Ilmu Kesehatan Universitas Warmadewa dharmestiwijaya@ gmail.com

${ }^{2}$ Fakultas Kedokteran dan Ilmu Kesehatan Universitas Warmadewa anak.indraningrat@gmail.com

${ }^{3}$ Fakultas Kedokteran dan Ilmu Kesehatan Universitas Warmadewa masyeniputu@yahoo.com

${ }^{4}$ Fakultas Kedokteran dan Ilmu Kesehatan Universitas Warmadewa omangbabe@yahoo.com

\section{PENDAHULUAN}

Kanker payudara dan kanker serviks merupakan jenis kanker dengan angka kejadian dan angka kematian tertinggi pertama dan keempat pada wanita di dunia (Bray et al, 2018). Di Indonesia, kasus kanker payudara mencapai 30.5\% dari keseluruhan kanker yang terdiagnosa dan berkontribusi sebesar $21.5 \%$ sebagai kanker penyebab kematian pada wanita (Mardela et al, 2015). Sebagian besar kasus kanker payudara terdiagnosa pada stadium yang tinggi sehingga menyulitkan penyembuhan dan kerap berujung pada kematian (Setyowibowo et al, 2018; Mardela et al, 2015). Sementara itu, prevalensi kanker serviks berdasarkan data dari 13 pusat patologi di Indonesia mencapai 31\% dari 10 jenis kanker yang umum ditemukan pada wanita (Nuranna et al, 2012). 
Lemahnya pengetahuan akan deteksi dini dari penyakit kanker payudara dan kanker serviks telah memicu meningkatnya angka kematian (Setyowibowo et al, 2018; Mardela et al, 2015; Nuranna et al, 2012). Pengetahuan terhadap kanker payudara dan serviks merupakan keahlian yang semestinya dikuasai oleh setiap wanita untuk mendeteksi dini keberadaan penyakit ini (Kemenkes RI, 2015). Pengetahuan tentang kanker payudara dan kanker serviks meliputi: i) gejala kanker, ii) faktor risiko umur, dan iii) risiko berkesinambungan (life time risk) (Setyowibowo et al, 2018, Nuranna et al, 2012). Sejumlah kemampuan dasar yang wajib dikuasai dan dilakukan terkait deteksi dini kanker payudara meliputi: i) Pemeriksaan rutin melalui perabaan (palpasi) dapat dilakukan secara mandiri di rumah dengan berdiri dan meraba payudara di depan cermin, atau dilakukan oleh petugas medis, dan ii) screening rutin setiap 2 tahun sekali dengan metode mammogram dan USG payudara (Mardela et $a l$, 2015). Sementara itu pemeriksaan pap smear dan tes DNA HPV merupakan metode untuk mendeteksi gejala awal kanker serviks pada wanita (Nuranna et al, 2012).

Kelompok wanita pedagang canang di Pasar Kreneng adalah salah satu kelompok yang kurang memahami faktor risiko penyakit kanker payudara dan kanker serviks. Kelompok ibu penjual canang di pasar Kreneng Denpasar terdiri dari kurang lebih 40 ibu-ibu dan pada umumnya memiliki pemahaman yang rendah akan faktor risiko penyakit kanker payudara dan kanker serviks. Deteksi dini kanker payudara dan kanker serviks sebelum kanker menyebar dapat membantu dalam meningkatkan keberhasilan pengobatan. Oleh karena itu, kesadaran dan pengetahuan masyarakat dalam mendeteksi sendiri gejala-gejala kanker payudara dan kanker serviks sedini mungkin sangat diperlukan untuk dapat mengurangi morbiditas dan mortalitas yang disebabkan oleh kedua penyakit ini.

\section{METODE PELAKSANAAN}

Kegiatan penyuluhan mengenai deteksi dini kanker payudara dan serviks pada kelompok pedagang canang di Pasar Kreneng, Denpasar dilakukan melalui metode sebagai berikut:

1. Pelatihan mengenali gejala dan tanda-tanda penyakit kanker payudara dan kanker serviks, serta pelatihan melakukan pemeriksaan SADARI yang diberikan oleh tim dosen Fakultas Kedokteran dan Ilmu Kesehatan (FKIK) Universitas Warmadewa (Unwar).

2. Pelatihan teknik pemberian informasi mengenai deteksi dini kanker payudara dan kanker serviks oleh tim dosen FKIK Unwar kepada anggota kelompok wanita pedagang canang di Pasar Kreneng Denpasar, sehingga kader-kader ini diharapkan dapat menyebarkan informasi yang telah didapatkan kepada anggota lain yang tidak terpilih dalam PKMS ini serta kelompok ibu-ibu lainnya di Pasar Kreneng Denpasar.

3. Penyerahan bahan-bahan untuk penyebaran informasi mengenai deteksi dini kanker payudara dan kanker serviks.

\section{HASIL DAN PEMBAHASAN}

Pelaksanaan pengabdian masyarakat ini diawali dengan diskusi dan brainstorming oleh tim pengabdi dari FKIK Unwar dengan ketua kelompok pedagang canang wanita di Pasar Kreneng, Denpasar terkait permasalahan kesehatan yang umum dikeluhkan dan ingin diketahui lebih mendalam oleh anggota kelompok pedagang canang wanita. Diskusi dilakukan sebanyak tiga kali melalui tatap muka dan melalui sambungan telepon. Hasil brainstorming mengindikasikan mayoritas pedagang canang belum memiliki pemahaman akan bahaya kanker payudara dan serviks dan disepakati bahwasanya pengabdi dari tim FKIK Unwar akan memberikan penyuluhan terkait topik ini. Perwakilan pedagang canang ini berperan sebagai mitra dalam mengkoordinir kelompok wanita pedagang canang di Pasar Kreneng. Hasil diskusi menyimpulkan kegiatan penyuluhan berlangsung pada hari Selasa, 17 September 2019 pukul 07.30 - selesai bertempat di salah satu kios Pasar Kreneng. 
Tim pengabdi menyiapkan materi pelatihan berupa power point, video edukasi, serta soal-soal pretest dan postest. Pelatihan diberikan kepada lima orang kader yang merupakan anggota Kelompok Wanita Pedagang Canang Pasar Kreneng yang telah ditunjuk oleh ketua kelompok. Materi yang diberikan tim pengabdi mencakup gejala dan tanda penyakit kanker payudara dan serviks, pemeriksaan SADARI, serta teknik pemberian informasi oleh para kader kepada anggota kelompok lainnya. Bahan-bahan untuk penyebaran informasi berupa video dan leaflet juga telah diberikan. Dokumentasi saat penyuluhan dan pelatihan dapat dilihat pada Gambar 1 dan 2.

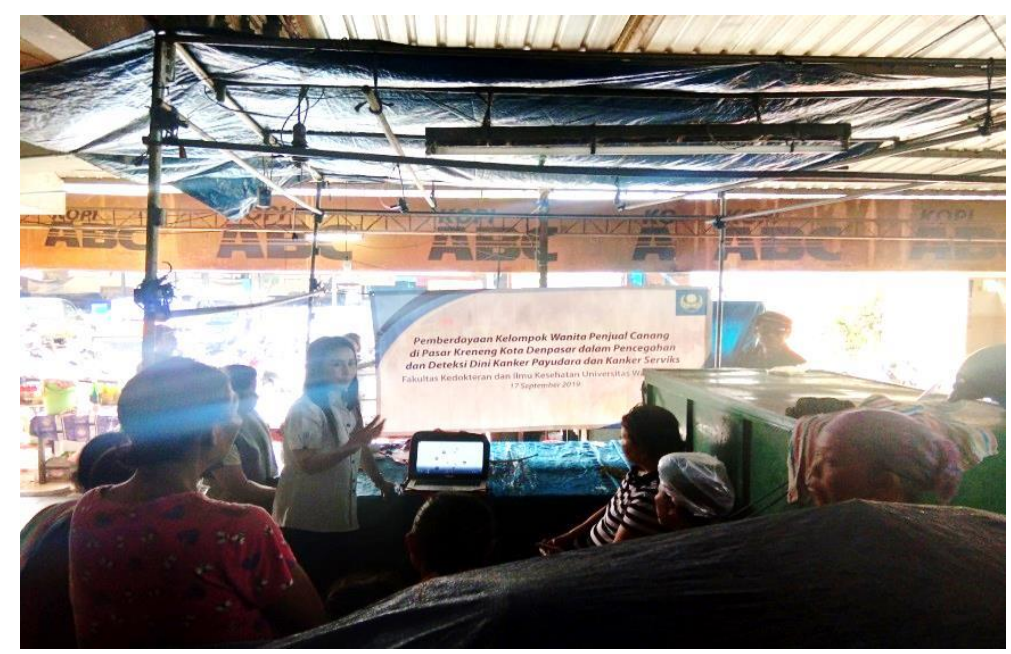

Gambar 1: Pemberian penyuluhan dan pelatihan terkait deteksi dini kanker payudara dan serviks pada kader-kader terpilih yang mewakili kelompok pedagang canang di Pasar Kreneng, Denpasar.

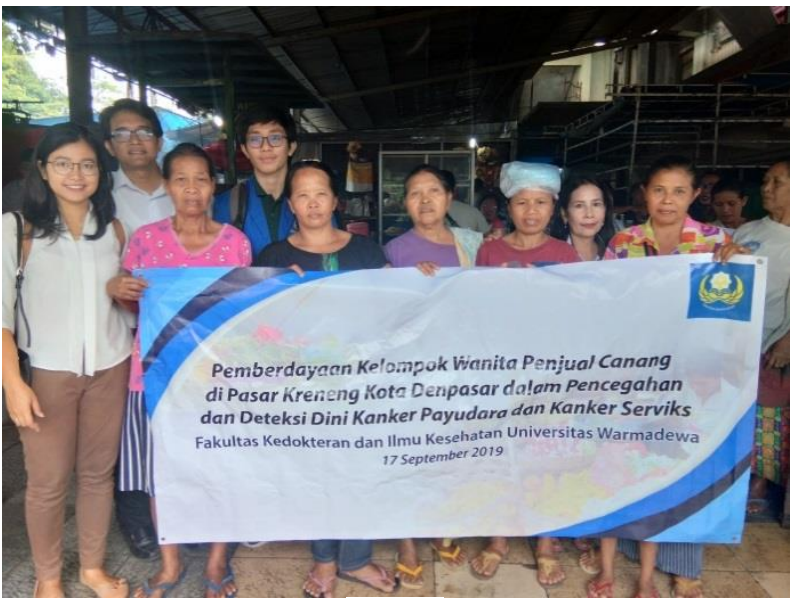

A

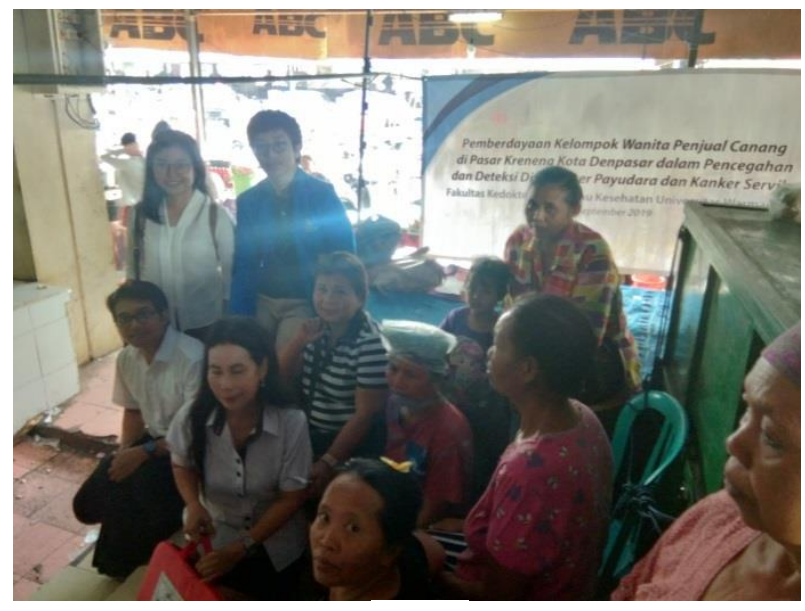

B

Gambar 2: A. Foto bersama tim pengabdi FKIK Unwar dengan para kader. B. Suasana diskusi selama pelatihan.

Hasil pretest dan posttest menunjukkan peningkatan pemahaman oleh para kader akan gejala, metode deteksi, dan upaya preventif kanker payudara dan serviks yang menandakan penyuluhan dan pelatihan sudah tepat sasaran. Pemahaman mengenai deteksi dini kanker payudara dan kanker serviks hanya sebesar $20 \%$ dari peserta sebelum diberikan materi penyuluhan. Hasil posttest pemahaman materi deteksi dini adalah sebesar $80 \%$, menunjukkan bahwa program cukup berhasil dalam meningkatkan pemahaman deteksi dini kanker pada wanita. Selanjutnya monitoring dan pendampingan berkala akan dilaksanakan dengan para kader terkait upaya edukasi dan sosialisasi deteksi kanker serviks dan payudara pada kelompok wanita pedagang canang di Pasar Kreneng, Denpasar. Diharapkan 
pendampingan ini kedepannya akan dapat memetakan permasalahan dan kendala yang dihadapi oleh para kader di lapangan untuk kemudian dicarikan solusinya bersama tim pengabdi FKIK Unwar.

\section{KESIMPULAN DAN SARAN}

Pengetahuan mengenai deteksi dini penyakit kanker payudara dan serviks pada wanita sangat diperlukan terutama bagi wanita dengan kesibukan tinggi dengan berbagai alasan, sehingga pengabdian seperti ini sebaiknya dilakukan secara rutin untuk membantu menurunkan mortalitas penyakit kanker. Hasil pengabdian ini mengindikasikan bahwa pelatihan yang diberikan telah meningkatkan pemahaman para kader pedagang canang terkait kanker payudara dan serviks serta metode deteksi dininya. Diharapkan para kader akan secara aktif mensosialisasikan pengetahuan yang telah didapat, tidak hanya kepada anggota kelompok pedagang canang lainya, namun juga kepada keluarga dan orang-orang di lingkungan mereka.

\section{UCAPAN TERIMA KASIH}

Ucapan terimakasih disampaikan kepada Dekan Fakultas Kedokteran dan Ilmu Kesehatan Universitas Warmadewa beserta Ketua Unit Penelitian dan Pengabdian Masyarakat (UP2M) FKIK Unwar atas dukungan finansial dan fasilitas yang diberikan sejak penulisan proposal hingga pelaksanaan kegiatan sehingga PKM ini dapat terselenggara dengan baik.

\section{DAFTAR PUSTAKA}

Bray, F; Ferlay, J; Soerjomataram, I; Siegel R.L; Torre, L.A; and Jemal,A. 2018. Global Cancer Statistics 2018: GLOBOCAN Estimates of Incidence and Mortality Worldwide for 36 Cancers in 185 Countries. CA Cancer J Clin. 68(6): 394-424.

Kementerian Kesehatan RI. (2015). Riset Kesehatan Dasar (RISKESDAS). Jakarta: Badan Litbang Kemenkes RI.

Mardela, A.P; Maneewat, K; Sangchan, H. 2015. Breast cancer awareness among Indonesian women at moderate-to-high risk. Nursing and Health Sciences. 19, 301-306.

Nuranna, L; Aziz, M.F; Cornain, S; Purwoto,G; Purbadi, S; Budiningsih, S; Siregar, B; Peters, A.A.W. 2012. Cervical cancer prevention program in Jakarta, Indonesia: See and Treat model in developing country. Journal of Gynecologic and Oncology. 23(3): 147-152.

Setyowibowo, H; Purba, F.D; Hunfeld, J.A.M; Iskandarsyah, A; Sadarjoen, S.S; Passchier, J; Sijbrandij, M. 2018. Quality of life and health status of Indonesian women with breast cancer symptoms before the definitive diagnosis: A comparison with Indonesian women in general. Plos One. 13(7). 